\title{
Evolution in Visual Communication of the Javanese Printed Wedding Invitations
}

\author{
Diah Kristina; Nur Saptaningsih \\ English Department, Universitas Sebelas Maret, Indonesia \\ Corresponding Author: diahkristina@staff.uns.ac.id
}

\begin{abstract}
Printed wedding invitations have been one of the most crucial aspects in the social organization among many countries like Brunei Darussalam, Iran, Egypt, and Persia. Javanese people also pay special attention to this social document as it represents social class, social status, prestige, and financial support allocated by the host. Evolution of printed Javanese wedding invitations represent social and economic pressures. The diasporic communities who were absent to earn a living brought a noticeable change by setting up the bride's parents' photographs in the invitations. 15 invitation texts were selected ranging from 1980 - 2017 used in Tawangmangu, Wonogiri and Sukoharjo, the eastern part of Central Java, Indonesia. There was a consistent regularity in terms of rhetorical structure. Functionally, the invitations have the same role of inviting prospective guests to share happiness in a more family-bound relationship. Inclusion of parents' photographs, map of the location, pre-wedding photos, wise words, calendar, the profile of the couple were indicators of transformation taking place. Later, the printing decision of the invitations is pretty much customer-driven informed by the customers' needs, values, and beliefs. Rhetorically the materialistically-driven social phenomenon was shown by an explicit gifts desired.
\end{abstract}

Keywords: evolution; wedding invitation; rhetorical structure; materialistically-driven

\section{INTRODUCTION}

Special attention has been put to examining printed wedding invitations as one of the significant social phenomena that relate to prestige, social class, and financial strata of the hosts. Countries like Brunei Darussalam, Egypt, Persia, Iran, and Indonesia have used this social document for bounding social relationship and presumably declaring social status. Rich families tend to disseminate hard, colorful, and luxurious wedding invitations that are costly. The less affluent however prefer the plain and light ones.

Marriage to Javanese people occupies one of the most important human life-cycles. The rests are life in the womb, birth, and death. Conducting a wedding reception and ceremony in the context of Javanese people, therefore, is a form of social management and organization. In the social organization of a wedding ceremony, people share their common ground in terms of kinship, associations, state systems, and living systems. In the real practice of conducting a wedding ceremony, community members work together to produce technology and engrave their tastes based on the social norms, values, beliefs, ideology, mysticism, art, and all elements of the human soul (Soemardjan \& Soemardi cited in Soekanto, 1990). Additionally, Koentjaraningrat (1990:80) emphasizes the crucial 'notion of working together among community members'. Collaborating among community members is widely known as 'gotong-royong', a common principle arises from the belief that people are not capable of living alone, let alone satisfying their own needs, including the need to conduct a wedding ceremony that requires a massive sharing of responsibility, human and material resources.

Wedding invitation belongs to the initial part of the social system in which many aspects such as time, venue, wedding rituals, entertainment, persons in charge, 
and audience to be invited should be taken into account. In setting up the time for the wedding to take place, the traditional Javanese will carefully consider the best timing for the best blessing. In particular, they differentiate between the time (saat) and timing (sangat). The venue of the wedding represents the social class and status of the prospective host; the rich family will normally select a reception hall in the town both for practicality and reputation while the less affluent prefer to have less prestigious wedding houses. Concerning materials of the wedding invitations, it is also a means of showing social status. Generally, only rich people can afford to produce luxurious, thick, and colorful wedding invitations with pre-wedding photos which are relatively more expensive.

Wedding invitations become very popular and widely used in Tawangmangu, Wonogiri and Sukoharjo, the eastern part of Central Java since the 1970s. This genre of wedding invitation has gone through many changes in the last forty years. The tailor-made printed wedding invitations were initially made by local publishers in the 1990s. Before that period, printed wedding invitations were sold in the market and stalls in ready stock stuff.

Evolution in the Javanese wedding invitations visually reflects social changes that relate to economic status, people's mobility, social recognition and prestige. To look at the genre convention, it is crucial to capture the relatively stable components of the wedding invitations and to what extent the evolution takes place. This social phenomenon has a similar process of change like the change in conceptual science as reported by Gross et al. (2002). Gross et.al argued that following the conceptual change in science as the result of various pressures, scientists' representational practices in terms of lexicogrammar, visual/graphic have been subject to pressures in the discursive environment producing the selection changes from the lexico-grammatical level to the macrostructural level.

Social pressures and continuing social demands trigger the evolution of the Javanese wedding invitations visually. According to Cap \& Okulska (2013), genre refers to clusters of conventionalized and predictable ways of goal-oriented communicative acting arousing from imperatives posed by constantly evolving sociocultural situations. The definition of genre proposed by Cap \& Okulska assumes that there is a dynamic relation between functional and linguistic aspects of genre. Many experts believe that the major corridor for change in genre is intertextuality (Chouliaraki \& Fairclough, 1999; Fairclough, 2006; Plett, 1991; Wodak, 2000) and the 'driving force is the fluid and shifting character of genres occupying the complex and fast-evolving social fields' (Cap \& Okulska, 2013:6).

To linguists, the evolution of genres has been an interesting area to explore since changes in texts and discourses represent changes in social phenomena or vice versa. By using the interpretive ethnographical lens of analysis, hopefully, some thick description and substantial explanation can be provided as a piece of evidence that genre changes alongside with the social change and most probably the redefinition of function of the texts in question. Bearing in mind the aforementioned phenomena, this study tries to answer the questions regarding what textual and visual properties the printed Javanese wedding invitations have in common, how they textually, visually and contextually evolve and why they evolve the way they do? This study, therefore, aims at exploring and explaining the linguistic, visual and ethnographical phenomena taking place in the genre evolution of the printed Javanese wedding invitations by employing an analytical lens of the New Rhetoric as the backgrounding theory used in this study.

\section{GENRE AND THE NEW RHETORIC}

The new rhetoric (NR) approach is one of the approaches under the theory of genre. It has taken a more inductive approach to genre; that is to consider context and to give genre a more central role (Swales, 1990). Therefore, this approach is believed to be the most suitable to reveal how genre evolves by looking very closely at its context. The new rhetoric has paid more attention to helping students and novice professionals understand the social functions or actions of genres and the contexts in which these genres are used (Bazerman, 1988; Devitt, 1993; Freedman \& Medway, 1994; Miller, 1994).

Genre under the view of the new rhetoric is seen to be more 'flexible, plastic, and free' (Bakhtin, 1986:76). Though genres are dynamic as claimed by Bakhtin, being members of a communicative event they are static, having regular features and owned by a particular community. Culturally, wedding invitations represent the norms, values, and ideologies adopted by the Javanese community of users which make them conventionally constructed. Since genres are conventionally constructed, there are regularities in terms of form and meaning. These include their regular ways of approaching the texts (i.e. where, when, and why readers read it), in negotiating their way through the text (i.e. previewing the text, deciding what to skim and what part to be read closely), in constructing knowledge from the text, and in using the resulting knowledge (i.e. to perform an action, to make a decision, or to produce a piece of writing). 
Research done following the new rhetoric tradition has examined such issues as the historical evolution of genres (Atkinson, 1996); the process of revising and responding to editors and reviewers in writing scientific articles (Myers, 1990); the social impact of transferring genres into new contexts with different purposes (Freedman \& Adam, 2000); and the study of genres at the workplace (Dias et al., 1999; Paré, 2000). Studies following the NR approach tend to employ ethnographic rather than linguistic research tools. Besides, they usually make use of participant observation, interviews, and descriptions of physical settings, as well as analysis of texts to develop 'thick descriptions' of the contexts surrounding the genres. The New Rhetorician analysts study the attitudes and values of the communities that employ a certain genre.

According to Baumgartner \& Hensley (2006:214), "ethnographical research has a long history of inquiry developed from the academic disciplines of anthropology and sociology". In ethnographical research, a researcher studies an intact cultural group in a natural setting over a certain period. Ethnographical research primarily uncovers and describes beliefs, values, and attitudes that structure the behavior of a group (Baumgartner $\&$ Hensley, 2006).

The new rhetoric researchers believe in the crucial function of ethnographic methods in gathering data to obtain a thick or detailed description of the contexts surrounding genres and actions within these contexts (Hyland, 2002; Hyon, 1996). Ethnographic data collecting method is preferred because the primary objective of this approach is to provide insights into the social functions of genres or the situational context of genres. The reason for this is the notion that the production and interpretation of texts do not begin with individual performance but are informed by preceding events or background of other surrounding texts (Briggs \& Bauman, 1992; Fairclough, 1992a, 1992b; Lemke, 1992; Swales, 2000). Lemke (1992) calls this principle 'general intertextuality'. Likewise, Hanks (1989) argues that the 'now' of the textual production is a 'multi-layered construct' and that the 'right now' of any text highlights past and anticipated future. Supporting this view, Johns (1997:97) explains that 'we can safely say that every academic text draws from and depends on other texts and discourse experiences in some ways; and thus intertextual'.

Smart (1998) proposes the use of 'interpretive ethnography' to investigate the network of shared meanings that constitute reality within a professional community. Smart's (1992) study took place over a period of seven months in the Bank of Canada where he used observation, tape recordings of interviews and meetings, reading protocols, and textual analysis to explore the social dimension of the system-evaluation report, an important genre within the bank. Through this kind of activity, Smart (1993) was able to observe how the report was prepared, how its major claim was argued, and how it was comprehended and used'. Interpretive ethnography allows us to study how members of a specific professional community participate in the knowledge-producing and knowledge-consuming activities within their professional culture, which according to Bhatia (2004) is helpful to understand more fully the community's meaning-making activity. Though interpretive ethnography is beneficial, Smart (1998:35) introduces the term analytical space in which he advises a researcher to preserve an adequate distance from the ideology of the community. The positive point of doing peripheral observation is that the researcher can set an analytical space to allow detachment in exploring the ideology of the community. Thus, there should be a balance between engagement and detachment in exploring the ideology of the community.

Bhatia (2004:179) provides the following characteristics of interpretive ethnography. First, interpretive ethnography employs different kinds of data including both oral and written genres, first-hand experiences of the community members and their specialist terminology and stories about the historical development of the community. It also draws on multiple perspectives which offer similarities across informants' common perception. In other words, it refers to the concept of intersubjectivity. Finally, in his/her interpretation of genres, the researcher engages with members of the discourse community to map out the community's ideology, which is a form of 'social construction of reality'. In summary, Bhatia (2004) points out that interpretive ethnography is intended to map out the ideology of the discourse community through extended social engagement with informants.

Lillis (2008) argued the importance of ethnography at three different levels: ethnography as a method, ethnography as a methodology, and ethnography as deep theorizing. Ethnography as method means that the researcher's primary object is the text, and talks around the texts are collected and analyzed as additional or supplementary data. Such an approach is more common in particular fields of writing research than others, notably in English for Academic Purposes (Chang \& Swales, 1999; Harwood, 2006; Hyland, 1999, 2003; Kubota, 1998; Ventola \& Mauranen, 1991). In this approach, the researcher's main concern moves beyond the text, but the text remains the primary object and the analytic lens. 
Regardless of the specific linguistic and textual approach adopted (for example, linguistics, genre, rhetoric, discourse), philosophically, it remains predominantly formalist or textualist in nature (Horner, 1999). In this tradition of text-focused approach, the work of Odell et al. (1983) has been highly influential.

Ethnography as methodology focuses on a close study to the beliefs, social interactions, and behaviors of a small society involving participation and observation over a period of time, and interpretation of the data collected (Denzin \& Lincoln, 2011). To add, Lillis (2008) argues that ethnography as methodology involves multiple data sources and a strong foundation on the contexts of production to enable the researcher to track down the dynamic situated meanings and practices. Ethnography as deep theorizing, however, refers to efforts of the researcher to set up analytical tools to narrow the gap between text and context as the two are generally conceptualized as separate and distinct phenomena.

There were previous studies on genre evolution conducted. Singh (2015) in his study found that the genre of autobiography in Europe has mostly focused on individual experience often marked by a literary language and a sophisticated mode of presentation, whereas the recent autobiographies in the non-Western world record the collective experience of a specific group, often socially disadvantaged like Dalits, women, AIDS and cancer patients, sex workers and very recently domestic maids. In the latter case, the autobiography becomes the testimonial voice of a subaltern people be it in terms of race, religion, caste, color, gender or physical challenges, with the protagonist in the role of a victim or a witness or both. The accumulated injustices find a literary outlet and telling one's story translates into a cathartic experience and/or a means of political resistance. In this case, the veracity of the statements becomes more important than the skills in language and creative writing. The "auto" of the autobiography is turned into a collective "auto".

Gregersen (2011) shows that technology has played an important role in digital game genre developments and that the concept of interaction modes is a helpful addition to existing game genre theory frameworks, especially in the context of technologies. He concludes that genre theory should be able to take on board the concept of interaction modes to identify salient patterns of generic physical interaction as an important part of the genre understood as provinces of meaning. Technology and the connections to the physical embodiment can be key components in both game and communication genre developments. Genres may move and cross-breed across media technologies, but technologies and embodiment may also matter in genre.

Martynuska (2009) examined the development of the western genre at various stages of American history of movies. It concludes that the western movie represents adventure, achievement, optimism for the future, the beauty of the land, and the courage of the individuals who won the land. The classic western can be an allegory of the fight between good and evil. American values - individualism, self-reliance and equality of opportunity - were all present in both the frontier life and westerns. Movie-makers used westerns to comment on historical and political events. The analysis of the historical background and the changes of the American society prove there is a connection between the society and the western. Along with the changes in American society the western genre transformed as well. With the development of new perceptions, some issues were presented differently. Especially the image of Native Americans was completely revised as Americans became more sensitive towards ethnic minorities - the 'others.' Behind the simple plot and the characters, there is a hidden message.

Additionally, Paré \& Roy (2002) investigated the evolution of an education journal for over 43 years. The journal began life in 1954 as The Slow Learning Child, became The Exceptional Child in 1976, and continues today as The International Journal of Disability, Development, and Education. The changing title itself suggests an evolution in consciousness and constituency that provides the background for the study. Despite an initial determination to serve both university-and-schoolbased educators, a rhetorical analysis of the journal's changing discourse demonstrates a gradual shift away from the classroom and the concerns of practitioners and toward the discourse of experimental research and the knowledge it produces.

Concerning other previous studies on ${ }^{1}$ genre evolution, this study has its novelty in terms of type of text and its context. Therefore, it is expected that this work can contribute significantly to the genre evolution landscape, especially in terms of social and textual notions of Indonesian and in particular Javanese beliefs and values.

\section{METHODOLOGY}

Under research methodology, some sub-topics are arranged successively as follows:

\section{Research Design}

This research belongs to an interpretive ethnographic 
study of Javanese printed wedding invitations that employs different kinds of data including both oral and written genres, first-hand experiences of the community members and their specialist terminology and stories about the historical development of the community. Lillis (2008) explained that ethnography as a method means that the researcher's primary object is the text, and any information around the texts are collected and analyzed as supplementary data. In this approach, the researcher's main focus moves beyond the text, but the text remains the primary object and the analytic lens. Bhatia (2004) states that interpretive ethnography aims at mapping out the ideology of the discourse community through extended social engagement with informants.

\section{Texts Used}

The texts used were 15 printed wedding invitations written in the Javanese language published in the 1980s up to 2017. For the texts produced in the 1980s, they were collected from the market and old kiosks while the rest were gathered from local publishing companies and individuals living around Tawangmangu, Wonogiri and Sukoharjo regencies.

\section{Data and Data Resources}

The data used in this study were words, phrases, clauses, and sentences taken from the 15 printed wedding invitations collected. 15 printed Javanese wedding invitations as the source data were gathered from the market, old kiosks, local publishing companies, and individuals. The visual appearance of the wedding invitation texts is provided at the appendix. Besides, a series of in-depth interviews were also conducted with five informants coming from the local publishing companies, community leaders, and community of users with the assumption that they had sufficient genre knowledge about the wedding discourse and were active users as well. Therefore, they have relatively similar perceptions on the issues in question and thus the notion of inter-subjectivity has been fulfilled.

\section{The Technique of Collecting Data}

Because this research is an interpretive ethnographical study of the Javanese wedding invitations, the scrutinization of the texts and exploration on the surrounding text phenomena had drawn the researchers to employ the techniques of collecting data as follows:

a. Data collecting method via observation. Field observation is meant to witness the way the wedding invitations were prepared and used by the discourse community members. b. Ethnographic data collecting method. It refers to the activities of collecting texts of wedding invitations while observing the social functions of the genre in question. The reason for this is the notion that the production and interpretation of texts do not begin with individual performance but are informed by preceding events or background of other surrounding texts.

c. In-depth interview. Five informants were selected based on the assumption of their good genre knowledge on the wedding invitations as discourse community members. The questions were delivered in such a way to dig out insights about the social beliefs and values regarding the texts in question and their producing and consuming backgrounds and intentions. The researchers have binary functions as active participants and analysts of the cultural discourse and convention. Therefore, epistemologically, their perception is ontologically cross-checked during the data collection and analysis.

\section{Data and Data Analysis}

The textual analysis of the data was done following Lillis (2008) in which the researchers' primary object is the text, and any information around the texts was treated as supplementary data. The textual analysis is meant to reveal genre changes and regularities in the selected Javanese wedding invitation texts. The changes in genre cover issues such as the need of users and genre knowledge of users. In terms of form and content, the genre reproduction processes which were informed by the community's needs and pressures, and genre convention as the representation of users' norms and ideologies. While regularity of genre was explored in terms of textual and social properties, the composing and consuming processes.

Ethnographically, results of the interviews and observation were analyzed to identify the way wedding invitations were prepared, the way the discourse community of users participate in the producing and consuming processes, their values and beliefs on the wedding invitations, the discourse settings and context surrounding wedding invitations.

\section{Validity and Reliability}

The validity of data was achieved through the fact that the texts analyzed have titles of 'wedding invitation' (Serat Ulem) put on top of each front cover of the texts. Besides, kinds of data were also triangulated in terms of data sources and techniques for collecting them. While the 
reliability of the data was gained by making sure that the findings were consistently relevant to the data collected (Merriam, 2009).

\section{RESULT AND DISCUSSION}

The subtopic of result and discussion is divided into two sub-headings namely, the macrostructure and the microstructure of the printed Javanese wedding invitation.

\section{Macro Structure}

Discussion on the macrostructure of the wedding invitations will address successively the discoursal strategies, discourse community, and discourse ideology.

\section{Discoursal Strategies}

With regard to the discoursal strategy, the printed Javanese wedding invitations were constructed using religious perspective as an entry behavior. Javanese people generally take the wedding celebration as a sacred and religious momentum hoping for an eternal marriage for the wedding couple. Literally, the common motivation to invite guests is to beg for their prayers and be the witness in this very moment of happiness. However, implicitly the guests should know that receiving wedding invitations means allocating a certain amount of money or other household stuff like rice, sugar, eggs or cooking oil for the host. In big cities, money is preferred for practical reasons and usually is suggested by a particular picture of a saving box at the back cover of the invitation. There has been a very strong notion of materialism subconsciously penetrating the lives of the Javanese as argued by Ger \& Belk (1996).

Besides, social pressures and continuing demands to accommodate needs of the diasporic families to put photos of the bride's parents as a driving force for the guests to attend the wedding strengthens claims made by Cap \& Okulska (2013) who emphasized that the conventionalized and predictable ways of goal-oriented communicative action made by the communities were arising from 'imperatives posed by constantly evolving socio-cultural situation'. Likewise, Miller (1994) also stated that genre is dynamic and prone to change over time and to users' needs which is evident in the present study of the printed Javanese wedding invitations. The increasing demands to have pre-wedding photos and wedding organizers have opened up promising businesses including wedding make-up services, wedding boutique, wedding stage decoration, catering services, and rented wedding houses. For the affluent community members, wedding organization and management have gradually turned from community-based into professional-based activities. With the support of the digital promotion of wedding services, prospective hosts can plan their wedding reception and procession much earlier and easier according to the allocated budget owned.

\section{Discourse Community}

Considering the discourse community of users, there were interesting phenomena to note. According to Suwarya, owner of a publishing agency, production processes of wedding invitation underwent different noticeable trends. Before the year 2000, due to technological challenges, the texts were made without photographs, neither the wedding couple nor their parents, and the texts were produced in a single color. People commonly used pictures of dove couple, flowers, and rings as symbols of marriage. These invitations were offered as ready stock stuff sold in the market and kiosks in which activities done by the prospective host was only writing down the addressers and addressees manually. Evolution in the use of materials for wedding invitations in the 1970s was obvious with the uses of folded A4-sized rice papers and colored cellulose-free (HVS) papers. Invitations were presented in template-based printing, in which the template was readymade and the names of guests were written by hand. In the early 1990s, with the advancement of technology, the design and the paper used for the wedding invitation were improved. Borders were used with various patterns, which were commonly available in Microsoft Word. Invitations were also presented in several styles, for example with the utilization of embossed and gold letters, and scented papers. Starting from this era, symbols, like coupleddoves, rings, flowers, or characters of a couple have been completed with nicknames or initials of the couple written inside or near the picture.

Meanwhile, starting from the 1990s, pictures or images were used to inform that the prospective hosts expected money gifts instead of tokens of stuff, like flower buckets, home decorations, and staple food. Somewhere in the wedding invitations, it generally says 'Tanpa mengurangi rasa hormat, mohon tidak memberikan hadiah berupa kado" (Without being disrespectful, gifts are not preferable). In a much closer look, this phenomenon relates with materialism and global trends of openness in expecting gifts from future guests. Additionally, there has been a strong tendency of the modern Javanese people to express openly their expectations of having the guests attending in the public wedding venue rather than accepting them at home. The implication would be two folds. First, it relates to the prestige of the host or hosts of having high social status 
guests in great numbers to occupy the available chairs in the public hall. Secondly, they will have a strong confidence in expecting financial gifts rather than having gifts in the forms of token of stuff.

A change of trend took place after 2000 in which most of the invitations put relatively big photos of parents of the bride at the front cover. The trend was very popular in Wonogiri, Gunung Kidul and the suburb areas of Sukoharjo and Karanganyar while the pre-wedding photos of the wed couples initially happened after 2009 as reported by Suwarya:

The period of 2000 was marked with additional photos of the female wed's parents in the front cover of the wedding invitations. Most invitations set a big and attractive photo of the bride's parents. In contrast, beginning in 2009, the couple's prewedding photographs were widely used and positioned at the front cover, especially among the rich families (20 July 2013).

In suburban areas, these tendencies seem to be relatively permanent. However, when the closer observation was done to more metropolis areas, inclusion of the bride and bridegroom's parents at the invitation cover in their wedding invitations was very rare due to the feeling of annoyance.

In this period, moreover, hosts or customers seem to have the privilege to order customized wedding invitations based on their interests. During the planning phase, a process of negotiation between the invitation publisher and the prospective host took place. The community's meaning-making process (Bhatia, 2004; Smart, 1993) grows on needs and affordability basis, for example, the publisher will make sure whether a map of the venue, poems, pre-wed photos will be included or negotiation in terms of color, fonts, or thickness and sophistication of the wedding invitations. The procedures for preparing the wedding invitations normally follow a series of steps below.

1. Customers meet the printing assistant and show the photographs to be printed.

2. Customers have consultations on design with the printing/publishing agency.

3. Once they agree on the wedding invitation draft, approval is made by the agency.

4. The approved draft of the invitation is ready to print.

Other extra-textual activities done by the wedding hosts were slaughtering cows and distributing gifts to set up a pre-engagement approach to make sure that the receivers of the gifts will attend the wedding ceremony.
In Tawangmangu areas (Kalisoro, Mblumbang, and Gondosuli), there has been a tradition to include meat from the cow slaughtered; at least one cow for every wedding celebration. Normally, only very rich people can afford to serve meat from the slaughtered cows while the less-affluent families will rely on debts provided by financial agencies around. This community tradition so far has been burdening the wedding hosts. However, they have to comply with the established norm for prestige and social status reasons. The pre-wedding gifts provided by the prospective host usually were in the form of food put in a small basket consisting of cooked rice, boiled vegetables and coconut spices, fried chicken, eggs and bananas. These gifts functioned as psychological pressures or ethical bond to make sure that receivers of the gifts will attend the wedding reception. Beside problematic in terms of financial expenses for the wedding hosts, this tradition is also challenging in terms of distribution to the receivers due to geographical distance, time and energy.

\section{Discourse Ideology}

Mostly the people of Tawangmangu earn their living by farming. Their main farming products are vegetables and fruits and other variants of farming products like snacks and home-made food. Sukoharjo, the neighboring area, is famous for its farming products especially rice. This regency is widely known as a fertile farming area. Wonogiri, on the other hand, has more barren lands and most of the people transmigrate to other areas outside Java Island or temporarily live in big cities to work. Consequently, when they were about to hold a wedding ceremony, most of the people living in the homeland were hardly familiar with the wedding couple. This situation inspired the wedding hosts to set up their photographs on the front cover of the wedding invitation, instead of photos of the wedding couple, to have a better psychological engagement with the targeted addressees.

The fact that marriage occupies one of the most important life cycles among the Javanese made every effort including material and financial potentials to be used optimally. The careful calculation seems to be crucial to avoid debts after the wedding celebration as reported by the informants.

In the process of data collecting, data processing, and report writing, the researchers employed a balanced engagement and detachment approach by reflecting the wedding phenomena to avoid subjective judgment as suggested by Smart (1998). The process of consistent checks and balances among observation, text analysis and result of interviews were done reflectively. The triangulation in terms of data collecting method and 
diverse sources of data has assisted the researcher mapped out the community's ideology (Bhatia, 2004), namely a gradual movement from organizing wedding procession and reception as a purely social and community-based activity then turns into a more prestige-oriented, materially-driven, and professional-based activity.

\section{Micro Structure}

In terms of the physical appearance of the wedding invitation, a direct understanding of the social and economic status of the host can be obtained, especially at the period after the year 2000. The sophistication of design, quality of paper, and variation of colors used provides a clue to the price to be paid by the wedding hosts and therefore reflects their social and economic status. In line with the idea of celebrating and sharing the happiness of conducting the wedding ceremony, the invitations were made with typical lay-outing using a picture of flowers and flowery sketches. These invitations were produced based on the taste and preference of the customers informed during negotiations with the text producer. In a situation when the customers do not have sufficient genre knowledge of the text, the publisher was ready to offer different kinds of alternative.

There are three issues to be discussed here namely rhetorical structures of the wedding invitations, specific diction used, and the relationship established between the text producers and text consumers.

Table 1. Rhetorical structures of invitation in 1980-2017

\begin{tabular}{|c|c|c|c|}
\hline Rhetorical structure & $\begin{array}{c}\text { Invitation before } \\
2000\end{array}$ & $\begin{array}{l}\text { Invitation } \\
2000-2008\end{array}$ & $\begin{array}{l}\text { Invitation } \\
\text { after } 2009\end{array}$ \\
\hline $\begin{array}{l}\text { Front cover } \\
\text { Title } \\
\text { Date of the event } \\
\text { Name of addressee } \\
\text { Photo of parents of the female wed } \\
\text { Name and address of the addressers } \\
\text { Pre-wedding photo }\end{array}$ & $\begin{array}{l}\mathrm{V} \\
\mathrm{V} \\
\mathrm{V} \\
- \\
- \\
-\end{array}$ & $\begin{array}{l}\mathrm{V} \\
\mathrm{V} \\
\mathrm{V} \\
\mathrm{V} \\
\mathrm{V} \\
-\end{array}$ & $\begin{array}{l}\mathrm{V} \\
\mathrm{V} \\
\mathrm{V} \\
- \\
\mathrm{V} \\
\mathrm{V}\end{array}$ \\
\hline $\begin{array}{l}\text { Back cover } \\
\text { Name and address of the addressers } \\
\text { Map of location } \\
\text { Request for a prayer to the wedding couple (optional) } \\
\text { Quotation from the Qur'an verse } \\
\text { Name of printing agency } \\
\text { Photo of the wedding couple }\end{array}$ & $\begin{array}{l}- \\
- \\
\mathrm{v} \\
\mathrm{v} \\
\mathrm{v} \\
-\end{array}$ & $\begin{array}{l}\mathrm{v} \\
- \\
\mathrm{v} \\
\mathrm{v} \\
\mathrm{v} \\
-\end{array}$ & $\begin{array}{l}\mathrm{V} \\
\mathrm{V} \\
\mathrm{V} \\
\mathrm{V} \\
\mathrm{V} \\
\mathrm{V}\end{array}$ \\
\hline $\begin{array}{l}\text { Left inside } \\
\text { Opening } \\
\text { Name of the weds and their parents } \\
\text { Time and venue of the legal marriage oath }\end{array}$ & $\begin{array}{l}\mathrm{v} \\
\mathrm{v} \\
\mathrm{v}\end{array}$ & $\begin{array}{l}\mathrm{V} \\
\mathrm{V} \\
\mathrm{V}\end{array}$ & $\begin{array}{l}\mathrm{V} \\
\mathrm{V} \\
\mathrm{V}\end{array}$ \\
\hline $\begin{array}{l}\text { Right inside } \\
\text { Place and month of publication } \\
\text { Greeting/salutation } \\
\text { Formal invitation (religious greeting, introduction, } \\
\text { day/date/time/venue of wedding) } \\
\text { Reason for inviting (to give a prayer and support and } \\
\text { be the witness) } \\
\text { Expression of thanks } \\
\text { Pre-closing } \\
\text { Closing } \\
\text { Name of the host \& hostess } \\
\text { Additional host \& hostess }\end{array}$ & $\begin{array}{l}- \\
\mathrm{V} \\
\mathrm{V} \\
\mathrm{V} \\
\mathrm{V} \\
\mathrm{V} \\
\mathrm{V} \\
\mathrm{V} \\
\mathrm{V}\end{array}$ & $\begin{array}{l}\mathrm{V} \\
\mathrm{V} \\
\mathrm{V} \\
\mathrm{v} \\
\mathrm{v} \\
\mathrm{v} \\
\mathrm{v} \\
\mathrm{v} \\
\mathrm{V}\end{array}$ & $\begin{array}{l}\mathrm{V} \\
\mathrm{V} \\
\mathrm{V} \\
\mathrm{v} \\
\mathrm{V} \\
\mathrm{v} \\
\mathrm{v} \\
\mathrm{v} \\
\mathrm{V}\end{array}$ \\
\hline
\end{tabular}




\section{Rhetorical structures}

Textually, the Javanese invitations ranging from the 1980s up to 2017 have the following structures as presented in Table 1.

Due to technological problems, photos of the wedding couple and the bride's parents were not existing in the 1980s. Additionally, the name of the addressers, as well as addressees, were also written manually because the wedding invitations were pre-printed as ready stock stuff in the market and kiosks that the wedding hosts could buy. Besides, maps of the location were not considered important in the invitations produced before 2000. Most probably it has a connection with the mobility of the people at that time which was not as wide as right now.

\section{Figure 1. Samples of Javanese printed wedding} invitations in 1980-2017

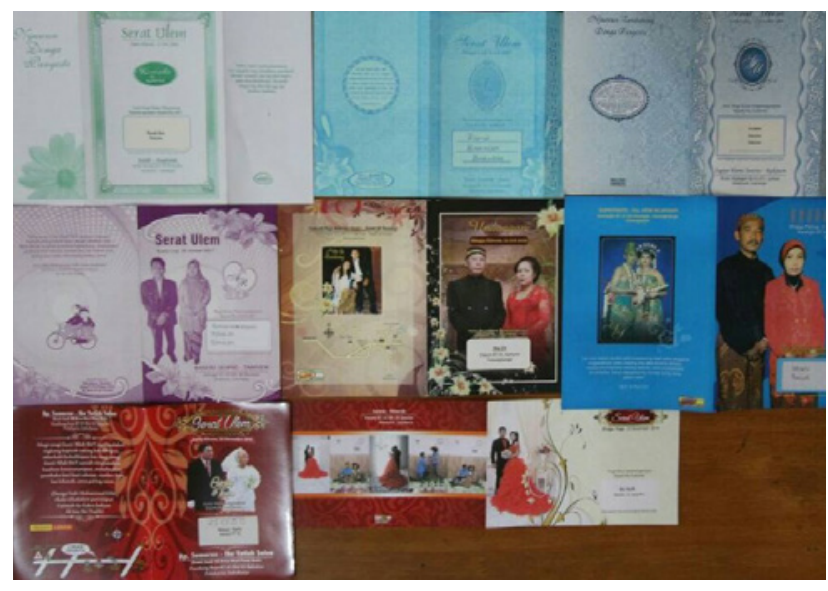

Arguably, photos of parents of the wedding couple were no longer existing after 2009 as the wedding couples believed that it was socially inappropriate as stated by the informant below.

Posting the photo of the bride's parents is considered inappropriate socially especially in the front cover of the invitation. This tradition started among the diasporic communities who held wedding celebrations in the homeland after a long time of absence (20 July 2013).

After 2009 with the increase of welfare, there was a demand for posting the pre-wedding photographs. Most probably it was not intended to make the prospective guests recognize the physical appearance of the future weds but more importantly for showing social prestige since the price of the pre-wedding service is expensive. Generally, only rich people can afford the pre-wedding photo sessions.
Lexically, greetings or salutations are almost always expressed in Arabic among Muslim wedding hosts 'Assalamu'alaikum Warahmatullahi Wabarokatuh' and usually written in short into Assalamu'alaikum. $W r . W b$ that means may the blessings of God be upon us. Additionally, the pre-closing uses Arabic greeting as well that says 'Wassalamu'alaikum Warahmatullahi Wabarokatuh'. Interestingly, the closing uses the high Javanese language (krama inggil) 'Atur taklim kula' which means 'My best regards'. Employment of the Arabic greeting has to do with the fact that Indonesia is one of the biggest Muslim populated countries in the world.

As suggested earlier, marriage to Javanese is regarded as a sacred and religious event, linguistically this value is expressed into 'kanthi sih nugrahaning Gusti Allah' (with the permission of God). Besides, the wedding itself is meant as a social gathering tied in mutual respect and love among the hosts and guests and a form of social and psychological responsibility as parents. God's permission, social and psychological responsibility as parents and an intention to share happiness among close friends and relatives are the three most common issues used as openers of the invitation. Likewise, a very common objective to invite guests is to witness the wedding event and give prayers to the couple 'saperlu hanjenengi saha paring donga pangestu wilujeng dhumateng anak kula temanten kekalih'.

\section{Relation of Text Producer and Text Consumer}

In terms of the relation between the text producers, in this case, is the prospective hosts, and the text consumers or the prospective guests, the hosts position themselves lower than the guests as they do expect the coming of the guests for two reasons, literally to witness and give prayers to the wedding couple. However, socially the guests' presence relates with two things, social prestige of the hosts and their financial return given by the guests for the wedding expenses. There is a convention flourishing in society that the host has the privilege to accept financial gifts as a concrete form of social collaboration as he/ she has invested some of their money on other people's previous wedding occasion. This is in line with Sunarto (2015:372) research findings, that tradition of giving 'gifts' or 'nyumbang' (in Central Java) and 'mbecek' (in East Java) functions as an effort to help each other and an investment which people can take back when they have wedding receptions of their own. On the other hand, the guests as text consumers may have more invitations to attend at the same day even at the same time, therefore, 
priority should be made. Closeness in relation, social prestige, geographical distance, and frequencies of the wedding celebration conducted by particular hosts are some points they normally consider. The decision to select which invitations to be responded generally is done by marking the calendar with a certain sign (red circle or cross on specific dates), a social phenomenon reported by Paré \& Smart (1994) in their previous study.

\section{CONCLUSION}

The evolution of printed Javanese wedding invitation genre as reported previously takes its form in the inclusion of parents' photographs, map of the location, and prewedding photos. In its later development, the printing decision of the invitations is pretty much customer-driven which is informed by the customers' needs, values, and beliefs. Rhetorically, almost all of the 15 invitation texts show a consistent regularity. One important thing to note is probably the tendency to express openly in terms of gift to the wedding couple, in cash or souvenirs like the phenomenon taking place in big cities which is more open and materialistically-driven.

For further research, it is advisable to study the evolution of other wedding invitations from diverse ethnic and religious groups using other languages with a much bigger number of texts. It will surely be more interesting to look at more than seventeen thousand islands and more than hundreds of languages all over the Indonesian archipelago.

\section{ACKNOWLEDGMENT}

The authors would like to extend sincere gratitude to all informants for providing essential information to complete this research paper and to the reviewers for invigorating and giving insightful comments and suggestions.

\section{REFERENCES}

Atkinson, D. (1996). The philosophical transactions of the Royal Society of London, 1675-1975: A sociohistorical discourse analysis. Language in Society, 25(3), 333-371.

Bakhtin, M. M. (1986). Speech genres and other late essays. Austin: University of Texas Press.

Baumgartner, T. A., \& Hensley, L. D. (2006). Conducting and reading research in health and human performance (4th ed.). Boston: McGraw Hill.

Bazerman, C. (1988). Shaping written knowledge: The genre and activity of the experimental article in science. Madison: University of Wisconsin Press.
Bhatia, V. K. (2004). World of written discourse: A genrebased view (advances in applied linguistics). London: Sage Publication.

Briggs, C. L., \& Bauman, R. (1992). Genre, intertextuality and social power. Journal of Linguistic Anthropology, 2(2), 131-172.

Cap, P., \& Okulska, U. (2013). Analyzing genres in political communication. Amsterdam and Philadelphia, PA: John Benjamin.

Chang, Y.-Y., \& Swales, J. (1999). Informal elements in English academic writing: Threats or opportunities for advanced non-native speakers. In C. N. Candlin \& K. Hyland (Eds.), Writing: Texts, processes and practices (pp. 145-167). London: Longman.

Chouliaraki, L., \& Fairclough, N. (1999). Discourse in late modernity. Edinburgh: Edinburgh University Press.

Denzin, N. K., \& Lincoln, Y. S. (2011). The Sage Handbook of Qualitative Research. USA: Sage Publications.

Devitt, A. J. (1993). Generalizing about genre: New conceptions of an old concept. College Composition and Communication, 44(4), 573-586.

Dias, P., Freedman, A., Medway, P., \& Paré, A. (1999). Worlds apart: Acting and writing in academic and workplace contexts. Mahwah, NJ: Lawrence Erlbaum Associates.

Fairclough, N. (1992a). Critical Language Awareness. London: Longman.

Fairclough, N. (1992b). Discourse and social change. Cambridge: Polity Press.

Fairclough, N. (2006). Language and globalization. London: Routledge.

Freedman, A., \& Adam, C. (2000). Write where you are: Situating learning to write in the university and workplace settings. In P. Dias \& A. Paré (Eds.), Transitions: Writing in academic and workplace settings (pp. 31-60). Cresskill, NJ: Hampton Press.

Freedman, A., \& Medway, P. (1994). Genre and the new rhetoric. New York: Taylor \& Francis.

Ger, G., \& Belk, R. W. (1996). Cross Cultural Differences in Materialism. Journal of Economic Psychology, 17(1), 55-77. https://doi.org/10.1016/0167-4870(95)000356

Gregersen, A. (2011). Genre, technology and embodied interaction: The evolution of digital game genres and motion gaming. Medie Kultur: Journal of Media and Communication Research, 27(51), 94-109.

Gross, A. G., Harmon, J. E., \& Reidy, M. S. (2002). Communicating science: The scientific article from the 17th century to the present. New York: Oxford University Press.

Hanks, W. F. (1989). Text and textuality. Annual Review of Anthropology, 18, 95-127.

Harwood, N. (2006). In(appropriate) personal pronoun use in political science: A qualitative study and a proposed 
heuristic for future research. Written Communication, 23(4), 424-450.

Horner, B. (1999). The birth of basic writing. In B. Horner \& M. Zhan-Lu (Eds.), Representing the other: Basic writers and the teaching of basic writing (pp. 3-29). Urbana, IL: National Council of Teachers of English.

Hyland, K. (1999). Disclipinary discourses: Writer stance in research articles. In C. N. Candlin \& K. Hyland (Eds.), Writing: Texts, processes and practices (pp. 99-121). London: Longman.

Hyland, K. (2002). Teaching and researching writing. London: Longman.

Hyland, K. (2003). Second language writing. Cambridge: Cambridge University Press.

Hyon, S. (1996). Genre in the three traditions: Implications for ESL. TESOL Quarterly, 30(4), 693-722.

Johns, A. M. (1997). Text, role and context: Developing academic literacies. Cambridge: Cambridge University Press.

Koentjaraningrat. (1990). Pengantar ilmu antropologi. Jakarta: PT. Rineka Cipta.

Kubota, R. (1998). Ideologies of English in Japan. World Englishes, 17(3), 295-306.

Lemke, J. L. (1992). Interpersonal meaning in discourse: Value orientations. In M. Davies \& L. Ravelli (Eds.), Advances in systemic linguistics: Recent theory and practice (pp. 82-104). London: Pinter Publishers.

Lillis, T. (2008). Ethnography as method, methodology, and deep theorizing. Journal of Written Communication, 25(3), 353-388. https://doi. org/10.1177/0741088308319229

Martynuska, M. (2009). The evolution of western genre resulting from social changes in the USA. Studia Anglica Resoviensia (Literary and Cultural Studies), 6, 59-67.

Merriam, S. B. (2009). Qualitative research: A guide to design and implementation (2nd ed.). San Francisco, CA: Jossey-Bass.

Miller, C. R. (1994). Genre as social action. In A. Freedman \& P. Medway (Eds.), Genre and the new rhetoric (pp. 20-36). London: Taylor \& Francis.

Myers, G. (1990). Writing biology: Texts in the social construction of scientific knowledge. Madison, WI: University of Wisconcin Press.

Odell, L., Goswami, D., \& Herrington, A. (1983). The discourse-based interview: A procedure for exploring the tacit knowledge of writers in non-academic settings. In P. Mosenthal, L. Tamor, \& S. A. Walmsley (Eds.), Research on writing: Principles and methods (pp. 220-236). New York: Longman.

Paré, A. (2000). Writing as a way into social work: Genre sets, genre systems, and distributed cognition. In P. Dias \& A. Paré (Eds.), Transitions: Writing in Academic and Workplace Settings (pp. 145-166).
Cresskill, NJ: Hampton Press.

Paré, A., \& Roy, R. (2002). The evolution of an educational journal: A genre study. Technostyle, 17(2), 31-54.

Paré, A., \& Smart, G. (1994). Observing genres in action: Towards a research methodology. In A. Freedman \& P. Medway (Eds.), Genre and the new rhetoric. London: Taylor \& Francis.

Plett, H. F. (1991). “Intertextualities.” In H. F. Plett (Ed.), Intertextuality (pp. 3-29). Berlin, New York: Walter de Gruyter.

Singh, R. (2015). On the genre of autobiography: Typology and evolution. The Delhi University Journal of the Humanities \& the Social Sciences, 2(2015), 76-86.

Smart, G. (1992). Exploring the social dimension of a workplace genre and the implications for teaching. Carleton Papers in Applied Language Studies, 9(1992), 33-46.

Smart, G. (1993). Genre as community invention: A central bank's response to its executives' expectations as readers. In R. Spilka (Ed.), Writing in the workplace: New research perspectives (pp. 124-140). Carbondale: Southern Illinois University Press.

Smart, G. (1998). Mapping conceptual worlds: Using interpretive ethnography to explore knowledgemaking in a professional community. The Journal of Business Communication, 35(1), 111-127.

Soekanto, S. (1990). Sosiologi: Suatu pengantar. Jakarta: Rajawali Press.

Sunarto. (2015). Budaya mbecek dalam perspektif agama, sosial dan ekonomi di Kabupaten Ponorogo. Presented at the Seminar Hasil-Hasil Penelitian dan Pengabdian kepada Masyarakat. Retrieved from http://eprints.umpo.ac.id/1997/1/38.SUNARTO.pdf

Swales, J. M. (1990). Genre analysis: English in academic and research settings. Cambridge: Cambridge University Press.

Swales, J. M. (2000). Language for specific purposes. Annual Review of Applied Linguistics, 20, 59-76.

Ventola, E., \& Mauranen, A. (1991). Non-native writing and native revising of scientific articles. In E. Ventola (Ed.), Functional and systemic linguistics: Approaches and uses (pp. 457-492). Berlin, Germany: Mouton de Gruyter.

Wodak, R. (2000). Recontextualization and the transformation of meanings: A critical discourse analysis of decision making in EU-meetings about employment policies. In S. Sarangi \& M. Coulthard (Eds.), Discourse and Social Life (pp. 185-206). Harlow: Pearson Education. 